\title{
Operational Remote Sensing of Sea Ice
}

\author{
JOHN C. FALKINGHAM ${ }^{1}$
}

\author{
(Received 6 June 1990; accepted in revised form 9 May 1991)
}

\begin{abstract}
The Ice Branch of Environment Canada's Atmospheric Environment Service is responsible for providing information about ice conditions in Canada's offshore areas. Principal clients include the Canadian Coast Guard, commercial shipping companies, the oil and gas industry and fishermen, who all require accurate information on ice distribution in near real-time. In order to provide this information, the Ice Branch employs a Challenger jet aircraft equipped with dual wide-swath synthetic aperture radars and a Dash-7 equipped with a real aperture side-looking airborne radar. These aircraft image approximately 100 million $\mathrm{km}^{2}$ annually. Radar image data from these aircraft are downlinked during flight via an S-band telemetry link to Coast Guard icebreakers and to satellite stations in the Ice Reconnaissance Data Network, which relays the data to the Ice Centre in Ottawa. There, the data are integrated with remotely sensed data from satellites and are used as the basis for ice analysis charts produced and distributed by radio facsimile on a daily basis.
\end{abstract}

Key words: sea ice, remote sensing, Arctic, radar, shipping, satellite, data communication

RÉSUMÉ. La direction des glaces du Service de l'environnement atmosphérique d'Environnement Canada a la responsabilité de fournir les informations sur les conditions des glaces pour les régions côtières canadiennes. Les principaux clients comprennent la garde-côtière canadienne, les compagnies de navigation commerciale, l'industrie du pétrole et du gaz et les pêcheurs qui ont tous besoin d'informations précises sur la distribution des glaces en temps presque réel. Afin de pouvoir fournir ces informations, la direction des glaces utilise un avion à réaction Challenger équipé d'un duo de SAR à bande large ainsi qu'un Dash-7 muni d'un SLAR. Les images récoltées par ces avions totalisent environ 100 millions de kilomètres carrés chaque année. En utilisant une ligne de communication télémétrique de bande $\mathrm{S}$, les images radars sont transmises en cours de vol aux brises glaces de la garde-côtière ainsi qu'aux stations satellites du réseau de données de reconnaissance des glaces (IRDNET) qui retransmettent ces données vers le Centre des glaces à Ottawa. Au Centre des glaces, ces images radars sont intégrées avec des données de télé-détection satellitaires et utilisés comme base pour la préparation quotidienne des cartes d'analyse des glaces qui sont distribuées par fac-similés radio.

Mots clés: glace de mer, télé-détection, arctique, radar, navigation, satellite, communications digitales

\section{INTRODUCTION}

Within the Canadian federal government structure, the Atmospheric Environment Service (AES) of the Department of Environment is responsible for the provision of information on atmospheric, sea state and ice conditions for the safe and efficient conduct of social, cultural and economic activities. The Ice Branch is the AES component that provides information on lake ice, sea ice and icebergs in the navigable waters of Canada's economic zone. The Ice Centre, located in Ottawa, is the operational headquarters for the branch.

The major clients for this information include the Canadian Coast Guard, commercial shipping companies, the oil and gas industry and fishermen, who all require accurate information on current and predicted ice conditions in near real-time. This paper describes the operational system used by AES to provide this information.

\section{OPERATIONAL AREAS}

Table 1 (Mullane, 1984) identifies the major operational areas and times of year for which ice data are collected. In addition, one or more "round robin" missions lasting approximately one week are conducted during the winter months for the purpose of collecting archival data on the winter ice characteristics throughout the Canadian Arctic.

During the winter months, December to April, when the southern areas are of primary importance, the two major aircraft are based in Gander and Halifax. In mid-June, one aircraft is deployed to Inuvik, from where it covers the Western Arctic until November. The other aircraft operates between Gander and Iqaluit while the ice recedes along the Labrador coast, then between Iqaluit and Resolute Bay as the ice in Hudson Bay and Davis Strait decays, finally relocating to Resolute Bay from July to November to support activity in the Central and Eastern Arctic.

\section{Airborne Ice Reconnaissance}

Ice data acquisition is heavily dependent on remote sensing, both from aircraft and satellite. Surface measurements from ships and shore stations provide valuable ground truth information.

The most important source of ice data is the reconnaissance aircraft, which currently number three. Aerial reconnaissance is done primarily with imaging radar that can map the ice surface in all weather conditions and at all times of the day or night.

The newly commissioned Challenger jet aircraft owned and operated by INTERA under a contract with the Ice Branch is the flagship of the fleet. It carries two synthetic aperture radars (SAR), which image a $100 \mathrm{~km}$ swath on each side of the aircraft to a resolution of $25 \mathrm{~m}$ (Fig. 1). An optional fine-scale mode on each radar provides $15 \mathrm{~m}$ resolution over a $60 \mathrm{~km}$ wide swath. Table 2 (INTERA, 1987) provides details on the radar performance specifications. The radar data is displayed in real-time in hard copy and terminal display fashion on the aircraft and is recorded in the on-board computer. A telemetry downlink system allows the SAR data to be transmitted to ships and to the Ice Centre while the aircraft is in flight. Missions

TABLE 1. Ice reconnaissance priority areas

\begin{tabular}{ll}
\hline \hline 1. Beaufort Sea & May - November \\
2. Gulf of St. Lawrence & January - March \\
3. Labrador Coast/ & \\
$\quad$ East Newfoundland & January - June \\
4. Davis Strait/Baffin Bay & May - Decermber \\
5. Parry Channel & May - December \\
6. Queen Elizabeth Islands & June - November \\
7. Central Arctic & June - November \\
8. Foxe Basin/Hudson Bay & June - November \\
9. Great Lakes & January - April \\
\hline \hline
\end{tabular}


covering $3500 \mathrm{~km}$ and lasting 5 hours are normally conducted every two or three days. The aircraft flies at high altitude and high speed, so visual reconnaissance is not possible.

A Dash-7 turbo-propeller aircraft owned by the government and operated under contract is the other major workhorse of the fleet. It carries a single side-looking airborne radar (SLAR), which images a $200 \mathrm{~km}$ wide swath $-100 \mathrm{~km}$ on each side of the aircraft. The resolution of the SLAR is variable, ranging from about $40 \mathrm{~m}$ close to the aircraft to several hundred metres at the far range. The radar data are displayed in hard copy in real-time on the aircraft and are recorded in the on-board computer. A telemetry downlink system, similar to that on the Challenger, allows the SLAR data to be transmitted to ships and to the Ice Centre while in flight. Additionally, this aircraft carries a Laser Profilometer to accurately measure the dimensions of ice surface features and a Zeiss mapping camera for visual truthing of the radar data. The aircraft is outfitted with a top bubble to allow visual reconnaissance. Missions covering $1500 \mathrm{~km}$ and lasting 6-7 hours are normally conducted every two or three days.
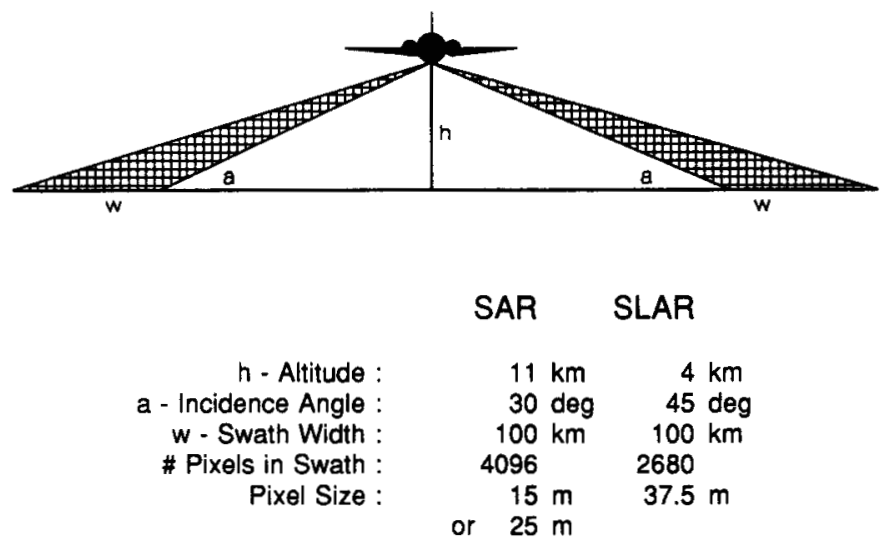

FIG. 1. Airborne radar geometry.

TABLE 2. Challenger SAR performance specifications

\begin{tabular}{ll}
\hline \hline Radar type & fully focused strip map; SAR, airborne \\
Frequency & X-band \\
Polarization & HH \\
$\begin{array}{l}\text { Slant swath width } \\
\quad \text { wide swath mode }\end{array}$ & $102.4 \mathrm{~km}$ each side \\
$\quad$ narrow swath mode & $61.4 \mathrm{~km}$ each side \\
Grazing angle (11 000 m) & \\
$\quad$ near range & $30^{\circ}$ \\
$\quad$ far range (wide swath) & $5.07^{\circ}$ \\
$\quad$ far range (narrow swath) & $7.58^{\circ}$ \\
Range resolution & \\
$\quad$ wide swath mode & $30 \mathrm{~m}$ \\
$\quad$ narrow swath mode & $18 \mathrm{~m}$ \\
Azimuth resolution & $8.3 \mathrm{~m}$ \\
Pixel size & \\
$\quad$ wide swath mode & $25 \mathrm{~m}$ \\
$\quad$ narrow swath mode & $15 \mathrm{~m}$ \\
Altitude & $11 \mathrm{~km}$ above sea level \\
Sensitivity & better than $-30 \mathrm{~dB}$; sigma zero at maximum \\
& range \\
Dynamic range & $40 \mathrm{~dB}$ \\
Data format & 4096 bytes per scan line from each side \\
Annotation & 64 annotation bytes appended to each scan \\
& line (defining radar/aircraft parameters) \\
\hline \hline
\end{tabular}

A DC-3 propeller aircraft completes the fleet and is used only for visual reconnaissance on the St. Lawrence Seaway. It carries no remote sensors.

\section{Flight Planning}

An annual master plan is updated monthly to identify general requirements by month for the next 12 months. Two-week flight schedules are issued every Monday describing the general area of operations and the operating bases for the coming two weeks. Daily flight schedules prescribe the detailed tracks for the next day and more general tracks for the following two days.

The detailed tracks specify straight legs to be imaged by their start and end latitude/longitude positions, the altitude at which each leg is to be flown (subject to air traffic control), the swath width of the radar for each side of each leg and the approximate time of day that the leg is to be flown. The tracks are produced with the aid of a graphical flight planning system at the Ice Centre.

\section{Satellite Remote Sensing}

Airborne remote sensing data are heavily supplemented by data from remote sensing satellites. Of greatest use is the advanced very high resolution radiometer (AVHRR) data from the U.S. polar-orbiting meteorological satellites. The $2000 \mathrm{~km}$ wide swath, with a resolution of about $1 \mathrm{~km}$, provides an excellent synoptic scale overview of the ice distribution suitable for determining large-scale ice motion and directing aerial reconnaissance. These digital data are transmitted via communications satellite to the Ice Centre from receiving stations in Edmonton and Toronto within one hour of the satellite pass. Data from the SPOT satellite provide much better resolution but with a smaller swath and are received at the Ice Centre on couriered computer tapes from the Canada Centre for Remote Sensing receiving station at Gatineau.

Unfortunately, cloud cover affects the data from all of these satellite optical sensors and so there is no certainty that a particular satellite pass will provide useful imagery of the ice. This problem will be rectified somewhat in 1991, when SAR data from the ERS-1 satellite become available. These digital data will be delivered to the Ice Centre within six hours of their reception at the Gatineau satellite station.

Radarsat is to be launched in 1994, carrying a SAR in a polar orbit designed with ice monitoring as a primary objective. This satellite will provide weather-free images of the surface to a resolution of $50 \mathrm{~m}$ across a $500 \mathrm{~km}$ wide swath. The satellite orbit will ensure that any part of the globe between 71.5 and $75.5^{\circ}$ north latitude can be imaged at least once each day and that the area between 51.5 and $71.5^{\circ}$ north latitude can be completely imaged in three days (Parashar, 1990). The ERS-1 data reception, processing and communication network will be expanded to deliver data from both the Gatineau and Prince Albert satellite stations to the Ice Centre within three hours after the satellite pass.

In addition to the remote sensing data that are the backbone of the reconnaissance operation, visually observed information from ship- and shore-based observers provides valuable ground truth data. This information is transmitted to the Ice Centre in the form of coded charts and alphanumeric messages.

\section{ICE BRANCH COMMUNICATIONS}

Rapid communication of information is essential to the provision of a comprehensive ice information service, which 
clients can use to make knowledgeable decisions. The branch has developed, and is continuing to develop, a sophisticated communication system designed to place the best ice information in the hands of the decision makers as quickly as possible.

The ice reconnaissance aircraft are all equipped with data downlink systems to transmit radar image data from the aircraft down to the surface. Ships that need detailed knowledge of the ice, such as Coast Guard icebreakers, are equipped with systems that can receive the downlinked data and display the $15 \mathrm{~m}$ resolution radar images in real-time as the aircraft flies overhead. These STAR-VUE systems are produced by INTERA and provide additional functions that allow the shipboard operator to enhance the images, to determine the correct geographical position of the images and to plan the vessel's track through the ice field.

In addition, the Ice Reconnaissance Data Network (IRDNET) employs several ground stations located at strategic locations along the Canadian coast (Fig. 2) to receive the downlinked data from the aircraft (Telesat, 1989, 1990). These ground stations relay the data through a communications satellite to the Ice Centre. The aircraft downlink operates on a line-of-sight radio frequency, which provides a range up to $400 \mathrm{~km}$. During a mission, the aircraft will collect radar data and record them in the on-board computer. When the aircraft comes within line of sight of one of the ground stations, the recorded data are transmitted at about 30 times acquisition speed. The ground station receives this burst and relays it to the Ice Centre via satellite. In this manner, the Ice Centre receives the actual radar data within three hours after they were recorded and can immediately begin processing them into ice information products for dissemination to users.

In a similar fashion, the Ice Centre uses satellite communication channels to obtain remote sensing satellite image data from receiving stations across the country within a few hours after the satellite acquired the imagery.

Products, charts and bulletins are disseminated to ships at sea by radio facsimile systems in the same manner, and on the same frequencies, as weather information. A foreign ship entering Canadian waters need only tune its radio to receive weather information and it will get the ice information automatically. Special users, such as the Coast Guard, receive detailed charts via the Inmarsat communications satellite.

Land-based users receive charts and bulletins by telephone, telex and facsimile or, if the need is not urgent, by regular mail.

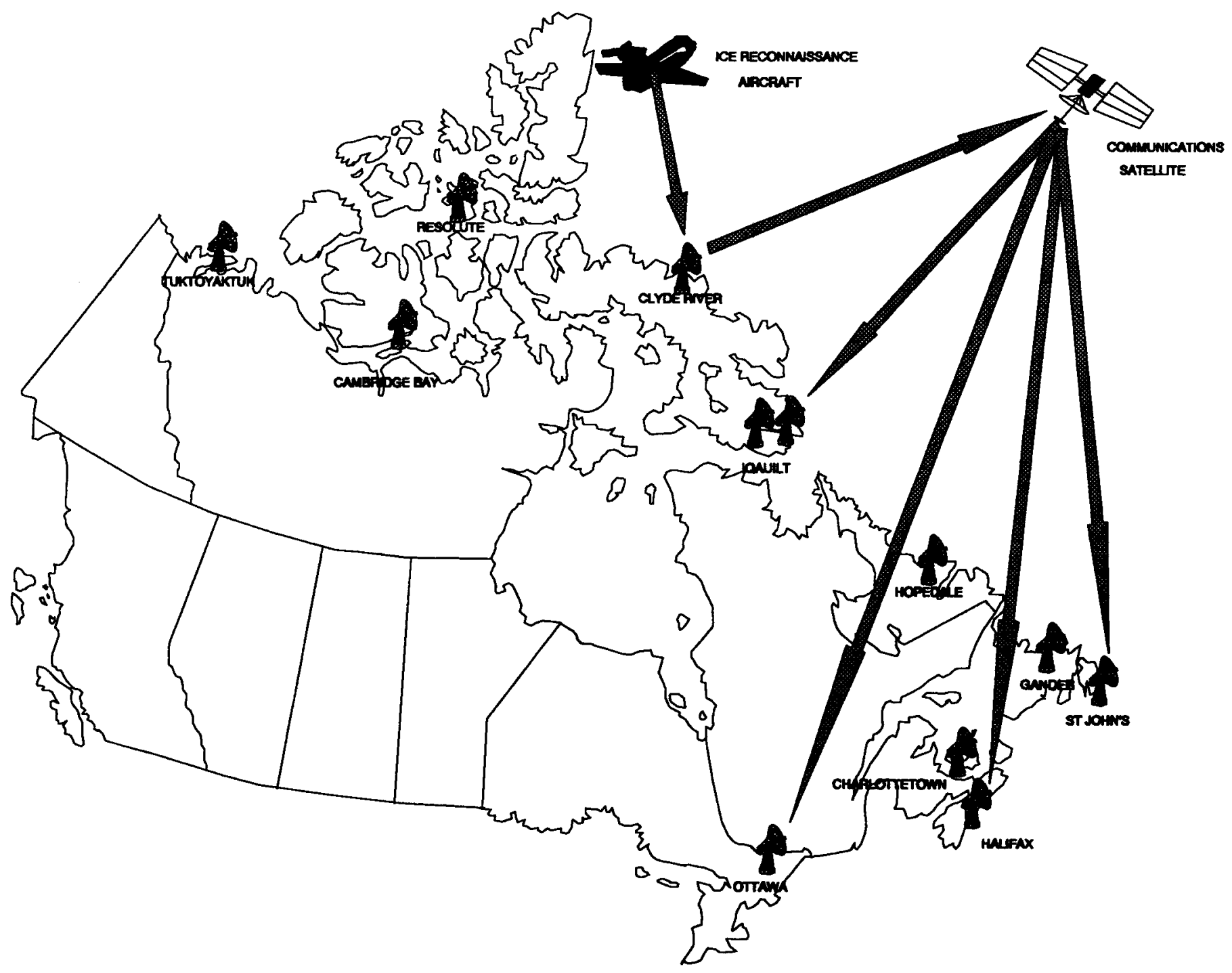

FIG. 2. Ice Reconnaissance Data Network (IRDNET). 


\section{ICE CENTRE DATA PROCESSING}

The Ice Centre is highly automated in order to maximize the productivity of the small number of ice experts. The sea ice program is based upon the Ice Data Integration and Analysis System (IDIAS) - a combination geographic information system and image analysis system that has been described in detail by Ramsay et al. (1988) and by Falkingham et al. (1989).

All of the data inputs previously described - aircraft SLAR and SAR, satellite imagery and surface observations that are received by the Ice Centre enter IDIAS, where they are automatically geo-referenced - that is, they are located on a common map background. This single activity, which requires a vast amount of computing power, results in the tremendous benefit of IDIAS, which is to allow the various data sets to be integrated and compared by direct overlay.

The data are displayed on work stations composed of twin high-resolution colour monitors. The operator interface uses windows and dynamic menus to provide efficiency and ease of use.

Various enhancement techniques are automatically applied to the imagery to provide the analyst with as much visual information as possible. A histogram equalization algorithm is applied to the radar data to use the full range of grey scales available on the 8-bit displays. A median filter is used to reduce speckle and an edge filter is applied to highlight ridges and leads. Multi-spectral AVHRR imagery is displayed in false colour to make maximum use of the information in all spectral bands, while at the same time providing an intuitive colour image (water is blue, ice is warm white, clouds are cool white, etc.). An ice/cloud discriminator (Ziegler, 1985) which consists of Band 1 on the red colour gun; (Band 1 Band 2)/(Band $1+$ Band 2) on the green gun; and Band $3 /$ Band 4 on the blue colour gun - is used to assist the analysts in separating cloud from ice.

The primary output products, the daily sea ice charts, are produced directly on the work station screen, with the imagery as a backdrop, using computer-assisted drawing techniques. The chart information, ice concentration, thickness and floe size are maintained in the geographic database for automatic input to a computer model of ice drift (INTERA, 1985). This model, based on winds and ocean currents, in turn produces predicted ice motion vectors, which are subsequently displayed on the IDIAS work station screen to assist the ice forecaster in producing the forecast products.

The output products are sent across the local area network to the Ice Centre Communications System (ICCS), which reformats products into digital text, computer graphics languages and facsimile formats for distribution to clients. Using the automatic computer dial-in facility of ICCS, clients can obtain bulletin products in facsimile or computer text formats and chart products in facsimile format or several computer graphics languages (Ice Centre, 1990).

\section{The Ice Archives}

All data acquired by the aircraft are archived at the Ice Centre. On the aircraft, all high-resolution SAR and SLAR data, as well as the compressed IRDNET data and various log files, are written on $8 \mathrm{~mm}$ Exabyte video cassette tapes. These compact tapes can hold up to 2 Gigabytes of data - enough for a complete mission. Additionally, a dry silver paper hard copy is produced on the aircraft in real-time. Both the hard copy and the tapes are sent to the Ice Centre after the flight for entry into the archive and can be made available to users. The tape format is documented in INTERA, 1989.

Additionally, all ice information products produced by the Ice Centre are archived. This includes the daily ice charts and bulletins, as well as weekly and monthly summaries and composite charts.

The archive contains thousands of catalogued data items, including aerial photographs, laser profiles, satellite images, charts, aircraft radar data and compiled alphanumeric data. Some of these data are maintained in digital form, while a great volume of older data remains in hard copy.

\section{SUMMARY}

This description of the Canadian government ice information service is accurate at the time of writing, but it should be recognized that the ice information services program undergoes constant evolution to meet continually changing needs and capabilities. Currently, a digital catalogue and archiving system is under development to ease data searches and retrieval from the archive and to assist with climatological analysis in support of global change investigations. Studies have been initiated to develop the capability to transmit image data to ships at sea in a cost-effective manner. Such evolution will continue within the ice program to ensure that Canadians have the information they need to operate in the ice in a safe and environmentally conscious manner.

\section{ACKNOWLEDGEMENTS}

Thanks go to all of the staff in the Ice Branch for providing much of the background information and detail for this paper over many months. In particular, I wish to thank David Pollock and Bruce Ramsay for their review and helpful comments; Richard Chagnon, who reviewed the paper and translated the abstract; and Phyllis Burge, who typed the manuscript. Colin Ramplee-Smith ably filled in for me to present the paper at the Yellowknife conference.

\section{REFERENCES}

CALIAN. 1990. Top level design document for an archive storage system for AES ice reconnaissance data. CCS \# AES-04 27 March 1990. Available at Calian Communications Systems Ltd., 300 Legget Drive, Kanata, Ontario K2K 1 Y5.

FALKINGHAM, J.C., RAMSAY, B.R., HENDERSON, D.A., and CARSON, L. 1989. The Ice Data Integration and Analysis System at the Ice Centre Environment Canada. North American Sea Ice Workshop, University of Massachusetts, Amherst, Massachusetts.

ICE CENTRE ENVIRONMENT CANADA. 1990. Ice Centre dial-in facility user's guide - Version 1.0. Available at Ice Centre Environment Canada, 373 Sussex Drive, Ottawa, Ontario K1A 0H3.

INTERA TECHNOLOGIES LTD. 1985. Regional Ice Model Implementation Guide, Vols. 1-4. Prepared for Ice Centre Environment Canada, 373 Sussex Drive, Ottawa, Ontario K1A 0H3.

1987. Provision of a comprehensive ice reconnaissance service for the Atmospheric Environment Service. Document Number CP87-001 (16 February 1987). Available at Ice Centre Environment Canada, 373 Sussex Drive, Ottawa, Ontario K1A 0H3.

1989. DMU Archive Tape Format. Document Number LCE081DOC013 (4 April 1989). Available at Ice Centre Environment Canada, 373 Sussex Drive, Ottawa, Ontario K1A 0H3.

MULLANE, T. 1984. Requirements for ERS-1 SAR data for Canadian ice program. Unpubl. report. Available at Ice Centre Environment Canada, 373 Sussex Drive, Ottawa, Ontario K1A $0 \mathrm{H3}$.

PARASHAR, S. 1990. RADARSAT mission requirements document. Unpubl. report. Available at Canadian Space Agency, Radarsat Project Office, 110 O'Conner Street, Ottawa, Ontario K1A 0 Y7. 
RAMSAY, B.R., HENDERSON, D.A., and CARSON, L. 1988. Real-time processing of digital image data in support of the Canadian Sea Ice Analysis and Prediction Programme. Proceedings of IGARSS ' 88 Symposium, Edinburgh. ESA Publications Division Reference SP-284.

TELESAT. 1989. AES Ice Branch IRDNET project design review. Project 2607-28, February 1989. Available at Telesat Canada, 1601 Telesat Court, Gloucester, Ontario K1B 5P4.
1990. IRDNET Project Phase II design review. February 1990. Available at Telesat Canada, 1601 Telesat Court, Gloucester, Ontario K1B 5P4. ZIEGLER, M.A. 1985. NOAA AVHRR Image Analysis Project Enhancements for operational ice forecasting and analysis. Unpubl. report. Available at Ice Centre Environment Canada, 373 Sussex Drive, Ottawa, Ontario $\mathrm{K} 1 \mathrm{~A} 0 \mathrm{H} 3$. 